\title{
Meet the New Members of the TMS Foundation Board of Trustees
}

\section{Kaitlin Calva}

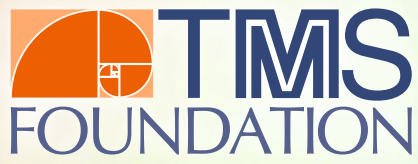

SOLUTION

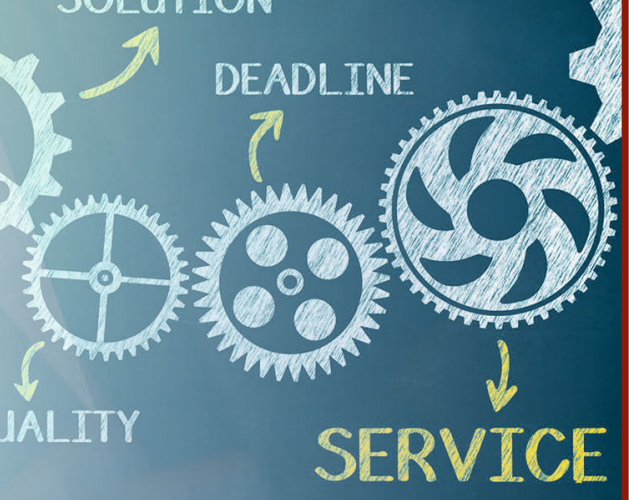

Similar to the role of the TMS Board of Directors in setting strategic priorities and leading the Society into the future, the TMS Foundation Board of Trustees represents the Foundation's mission, provides strategic direction for programs and funds, and engages in effective fundraising. They are the philanthropic stewards of the Society. Their commitment to providing financial assistance and careerbuilding experiences for students and young professionals helps to ensure a bright future for the minerals, metals, and materials professions.

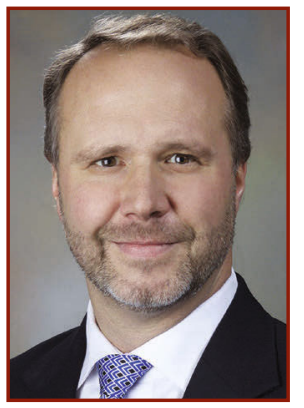

\section{Brad Boyce}

"I view my donation to the Foundation as a way to pay it forward," said Brad Boyce, distinguished member of the technical staff at Sandia National Laboratories. "As I have advanced in my career, each step has been facilitated by support from a network of colleagues, mentors, and advocates. TMS has provided a key role in helping me develop my network and learn about the advances across the world in materials research. By contributing to the Foundation, I am contributing to the development of the next generation of early-career researchers who are joining the TMS family and contributing in their own unique ways."

Boyce first became involved with the TMS Foundation when he received the Structural Materials Division (SMD) Young Leaders Professional Development Award in 2009. He attended the Emerging Leaders Alliance (ELA) program, supported through a registration grant from the Foundation, several years later and then became a donor as his engagement with TMS grew, from volunteering within the SMD to his most recent role as Programming Director on the TMS Board of Directors. "Not all professional societies have a philanthropic branch. I'm
The six individuals presented in the following pages were officially installed as the newest members of the TMS Foundation Board of Trustees at their March 2021 meeting. To find out how you can get involved with the TMS Foundation as a member of the Board of Trustees, contact Kimberly Cannon, Membership, Volunteerism \& TMS Foundation Department Head, TMS, at kcannon@ tms.org or 1-724-814-3118.

To learn more about the Foundation's mission, visit the About page at www.TMSFoundation.org

hopeful that I can help communicate the unique value of the Foundation as a sponsor for the development of earlycareer professionals. I'm also hopeful that we can expand the portfolio of services that the Foundation provides to enable a broader range of positive outcomes."

Though the COVID-19 pandemic has affected many aspects of TMS membership, such as the shared experience of attending in-person meetings, Boyce recognizes there is still a need to lift members up with the help of the Foundation. "Through this lens, we realize how fortunate we were to have the in-person TMSfacilitated meetings as forums for interaction. As we look to rebuild those connections, donations to the Foundation can help the Society continue to engage early members, who are especially isolated by the virus at a critical stage in their career and in need of that extra encouragement and support."

\section{"I'm hopeful that I can help communicate}

the unique value of the Foundation as

a sponsor for the development of earlycareer professionals."

\section{-Brad Boyce}




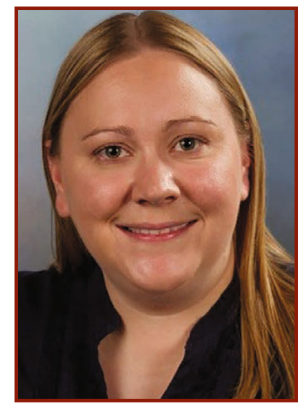

\section{Amy J. Clarke}

Currently an associate professor in the George S. Ansell Department of Metallurgical and Materials Engineering at the Colorado School of Mines, Amy Clarke notes that it's difficult to pinpoint her first involvement with the TMS Foundation. Receiving the 2008 Materials Processing \& Manufacturing Division Young Leaders Professional Development Award and 2013 TMS/Federation of European Materials Societies (FEMS) Young Leaders International Scholar Award, followed by attending the ELA program in 2016, helped to springboard her involvement in TMS. "I give annually to the TMS Foundation to help ensure that opportunities such as these continue to exist for young professionals. This has kept me active and engaged over the years," Clarke said.

"I recognize the positive impacts the TMS Foundation has had on my own early-stage professional development. It is imperative that we continue to cultivate our future leaders by annual giving to the TMS Foundation," she continued. "We must also strive to be a highly inclusive society. The Ellen Swallow Richards Diversity Award and Frank Crossley Diversity Award, supported by the TMS
Foundation, not only recognize established professionals, but also acknowledge the adversity experienced by some of our members. Their stories promote awareness and provide inspiration to the materials community."

While Clarke has been a member of many TMS committees and served as Membership \& Student Development Director on the TMS Board of Directors, she steps into a new role with the Society as member of the TMS Foundation Board of Trustees. "What I am looking forward to the most is learning more about the positive impacts the TMS Foundation is having on our members! I hope to help communicate these stories, as I'm sure they will inspire others to give back to the Society and promote the development of our leaders at all levels. I also hope to help expand scholarship opportunities for students."

"It is imperative that we continue to cultivate our future leaders by annual giving to the TMS Foundation."

-Amy J. Clarke

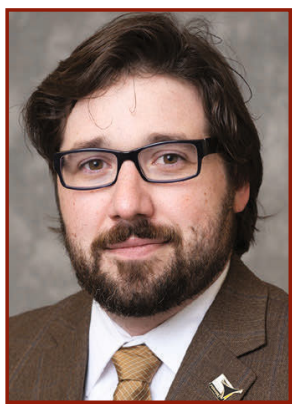

\section{John Howarter}

John Howarter, associate professor of materials engineering and environmental \& ecological engineering at Purdue University, is most looking forward to "meeting new people within TMS, both the donors and beneficiaries of the core Foundation programs." With the 2015 Extraction \& Processing

Division (EPD) Young Leaders Professional Development Award serving as his first introduction to the TMS Foundation, Howarter understands how support from the Foundation can make an impact.

"That was a transformational experience and it really opened up a lot of opportunities for me," he said. "As I continued to participate in TMS meetings and events, I began to notice that the TMS Foundation was behind some really great programs that were positively shaping our community of materials scientists and engineers."

"The TMS Foundation is central to our profession," he continued. "Its impact extends beyond a particular region or school and in that sense, we can have a very unique impact on young professionals in our field. I am drawn to my support of the Foundation because I have a certain amount of trust and familiarity with TMS through my participation in the annual meeting."

As a member of TMS for nearly 20 years, Howarter has been actively involved in several technical and functional committees. Most recently he served on the TMS Board of Directors as Public \& Governmental Affairs Director.

"The TMS Foundation is central to our profession. Its impact extends beyond a particular region or school and in that sense, we can have a very unique impact on young professionals in our field."

\section{-John Howarter}




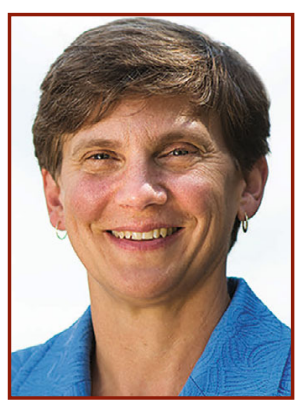

\section{Linda Schadler}

Linda Schadler, dean of the College of Engineering and Mathematical Science at the University of Vermont, first joined TMS at the encouragement of her professors after graduation. After beginning her academic career, she got involved with the TMS Education Committee through her department chair, Alan Lawley. "It all snowballed from there. The TMS leadership at the time was incredibly welcoming and I found colleagues that I learned a lot from, enjoyed hanging out with, and for whom I have tremendous respect."

“The TMS Foundation's commitment to supporting students is an important contribution to the materials community," Schadler remarked. In addition to these efforts, Schadler recognized the importance of promoting a more diverse and inclusive professional community through TMS's two diversity awards. "While the Foundation supports other programs, these are the ones
I am most passionate about. I am hoping I can help the Foundation realize some of their fundraising goals in these two areas."

"There are only a few ways for the materials community to help support their own. One way is, of course, by spending time mentoring students and young professionals," she noted. "But just as impactful are the funds we can spend to relieve the financial burden for students and to recognize their efforts in research. We owe it to our community to give back with time, talent, and, as appropriate, treasure. This is true in our local communities, but also our professional communities."

“...just as impactful are the funds we can spend to relieve the financial burden for students and to recognize their efforts in research."

\section{-Linda Schadler}

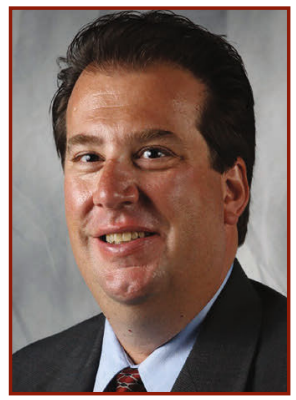

\section{Dan J. Thoma}

"I look forward to promoting enthusiasm to engage impactful activities that advance the profession," said Dan Thoma, director of the Grainger Institute for Engineering and professor of materials science and engineering at the University of WisconsinMadison. "My service and past roles within TMS have provided a large network of interactions, and I hope to engage that community for the next generation of the materials community."

Thoma has been involved in TMS and the TMS Foundation since about 1992, holding many roles within the Society throughout his membership, including as 2003 TMS President. He has also served on the Board of Trustees for the American Institute of Mining, Metallurgical, and Petroleum Engineers (AIME) and for the United Engineering Foundation (UEF), which has kept him actively involved over the years. "All of these organizations have strived to provide advancement for professionals in a materials and engineering career," he said. "In my opinion, the materials professions advance technology and increase quality of life. The TMS Foundation is one mechanism to sustain the future health of the professions."

Looking to the bylaws and mission of TMS, Thoma recognizes how the mission of the Foundation supports society at large by supporting the materials professions. "I think most of our current and future members want to make a positive impact on society. The belief that sustainable materials enable technology advancement for topics such as clean energy, transportation, communication, and safety is a powerful message."

"In my opinion, the materials professions advance technology and increase quality of life. The TMS Foundation is one mechanism to sustain the future health of the professions."

\section{-Dan J. Thoma}




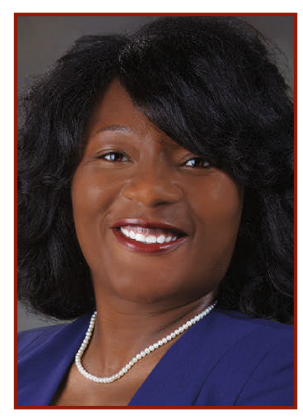

\section{Olivia D. Underwood Jackson}

"TMS has helped me to grow professionally and as a leader. It has also provided a platform where I could share my research; therefore, it is important that I continue to pay it forward through my interactions and financial support to provide opportunities for students and young professionals," said Olivia Underwood Jackson, principal member of the technical staff at Sandia National Laboratories. Jackson notes that attending the ELA program in 2017 was her first involvement with the Foundation, which provided her with invaluable leadership skills that have helped accelerate her career. This chance to grow professionally and hone her abilities has kept her active in TMS and the Foundation over the years.

Jackson also received the 2019 Frank Crossley Diversity Award from TMS which, as a first-generation college graduate, has a special meaning for her. "After experiencing firsthand, while working on my Ph.D., what it feels like to be excluded and to be met with resistance because of the color of my skin, it warms my heart to see TMS celebrate and take an active interest in diversity and inclusion. The work of diversity, equity, and inclusion is far from being done and requires each one of us to do our part to make this Society more inclusive."

In this new leadership role with the Foundation, Jackson hopes to ensure the success of the next generation. "I am looking forward to helping expand and maintain the current and future TMS funding avenues to support students and young professionals to be able to attend conferences and to develop professionally."

She continued, noting that: "Representation matters. I will be actively looking for roles where I can advocate for equity in TMS actions, champion diversity and inclusion, and push TMS in taking a bolder leadership role in increasing the recruitment, retention, and participation of historically underrepresented groups in materials science and engineering."

"... it is important that I continue to pay it forward through my interactions and financial support to provide opportunities for students and young professionals."

\section{-Olivia D. Underwood Jackson}

\section{The TMS Foundation Board of Trustees}

\section{Chair \\ Garry W. Warren \\ Professor Emeritus, University of Alabama}

\section{Executive Committee Representative} James Foley

Sigma-1 Group Leader, Los Alamos National Laboratory

\section{Trustees}

Viola Acoff

Associate Dean, University of Alabama

Brad Boyce

Distinguished Member of the Technical Staff,

Sandia National Laboratories

\section{Carl M. Cady}

Technical Staff Member, Los Alamos National Laboratory

Amy J. Clarke

Associate Professor, George S. Ansell Department of

Metallurgical and Materials Engineering,

Colorado School of Mines

\section{David DeYoung}

Director of Reserach \& Development (Retired), Alcoa

\section{Stanley M. Howard}

Senior Lecturer and Professor Emeritus, South Dakota School of Mines \& Technology
John Howarter

Associate Professor of Materials Engineering and Environmental \& Ecological Engineering, Purdue University

Marc Meyers

Distinguished Professor of Materials Science,

University of California, Santa Barbara

Ray Peterson

Technology Director, Real Alloy

Linda Schadler

Dean, College of Engineering and Mathematical Sciences, University of Vermont

David A. Shifler

Program Officer, Office of Naval Research

Robert D. Shull

NIST Fellow (Retired), National Institute for Standards and Technology (NIST)

\section{Dan J.Thoma}

Director, Grainger Institute for Engineering, and Professor, Materials Science and Engineering, University of Wisconsin-Madison

Olivia D. Underwood Jackson

Principal Member of Technical Staff,

Sandia National Laboratories

Secretary

James J. Robinson

TMS Executive Director 